\title{
The Level of Disclosure of Intellectual Capital at Jordanian Development Banks
}

\author{
Firas A.N Al-Dalabih ${ }^{1}$ \\ ${ }^{1}$ Irbid National University, Jordan \\ Correspondence: Firas A.N Al-Dalabih, Irbid National University, Jordan.
}

Received: August 13, 2018

doi:10.5539/ibr.v11n11p176
Accepted: September 21, 2018

Online Published: October 25, 2018

\begin{abstract}
This study aims at identifying the level of disclosure of intellectual capital at the Jordanian development banks. The study sample composed of a hundred individuals working at the National Bank to Finance Small Projects around the different governorates of the Hashemite Kingdom of Jordan. A questionnaire has been prepared and distributed over the study sample. ninety five Questionnaires have been retrieved; valid for the statistical analysis purposes with a percentage of $(95 \%)$.

The study results showed that the level of disclosure of intellectual capital with all its dimensions (human capital, customer capital and structural capital) at the Jordanian development banks was of a high level. The results also showed that there is a high level of awareness performed by the Jordanian development banks' employees in regard to the necessity and importance of the intellectual capital's disclosure.

The study was concluded with a number of recommendations among which were that the Jordanian development banks shall take notice toward increasing their workers' awareness regarding the importance of intellectual capital's disclosure, as well as applying this study over commercial and Islamic banks for the purposes of carrying out a comparison between them and the development banks.
\end{abstract}

Keywords: disclosure of intellectual capital, national bank for small enterprise development, Hashemite Kingdom of Jordan

\section{Introduction}

Interest in disclosure and transparency laws is increasing nowadays especially in money market as information plays a critical role in affecting the decisions of dealers in financial markets whether these decisions were related to sales or purchases or alike. (Tong, 2007)

Laws of disclosure and transparency are connected to the corporate governance which has become one of the most important aspects being applied in companies listed in the financial market, especially after losing many investors their trust in the financial market due to the misuse of financial statements played by companies' managers and auditors through not disclosing the data of financial and accounting reports and statements which in turn led to the expansion of global financial crises proved by the failure of huge companies. (Qabajah, 2008)

There are several studies that were concerned with the level of the disclosure of intellectual capital and its relation with governance. For example, the study of Abdifatah and Nazli (2013) clarified the existence of a positive effect for governance on the quality level of disclosure of intellectual capital in Malaysian Companies.

There are studies that handled the intellectual capital as a share in the partnerships' capital. This was explained in the study of Al-Hafiz (2012) which emphasized that the intellectual capital is considered the most valuable assets of the company; it also allocated for the individual human capital a capital share just like the financial shares of partners as well as transformed the human capital from the labor participation to the capital participation.

This study will identify the level of disclosure of intellectual capital at the Jordanian development banks.

\section{Problem of the Study}

Not disclosing data and information related to the companies' financial reports is considered a way of manipulation, due to being incomplete, the matter that demonstrates the managerial and financial position of the company in an unreal image which makes it subject to accountability later on. 
Intellectual capital is considered one of the most important information and data that supposed to be disclosed by companies and banks due to the importance of its components which are considered an integral part of the company's performance. Based on this, not disclosing the intellectual capital is considered as an insufficiency in the company's different reports in general and at the commercial banks in particular.

Based on this, we can define the problem of the study by the following main question:

What is the level of disclosure of intellectual capital at the Jordanian development banks?

Out of this question we have the following sub-questions:

1- What is the level of disclosure of human capital at the Jordanian development banks?

2- What is the level of disclosure of customer (relation/ external) capital at the Jordanian development banks?

3- What is the level of disclosure of structural (organizational/ internal) capital at the Jordanian development banks?

\section{Objective of the Study}

This study mainly aims at identifying the level of disclosure of intellectual capital at the Jordanian development banks.

Out of this main objective we have the following sub-objectives:

1- Identify the level of disclosure of human capital at the Jordanian development banks.

2- Identify the level of disclosure of customer (relation/ external) capital at the Jordanian development banks.

3- Identify the level of disclosure of structural (organizational/ internal) capital at the Jordanian development banks.

\section{Importance of the Study}

The importance of the study stems from the importance of the intellectual capital which forms the basis of the company, and the higher the level of development of the intellectual capital is the better the performance of the company becomes in different aspects.

Therefore, addressing the level of disclosure of the intellectual capital aspects and identifying the commitment of developed banks to this disclosure contribute in increasing the credibility of the bank and in increasing its competitiveness, which leads to its development and sustainability.

This study benefits all the parties dealing with the developed banks through clarifying the intellectual capital aspects that are disclosed within the banks' reports, which in turns makes them feel safe and confident in dealing with banks.

\section{Hypotheses of the Study}

Ha1: The level of disclosure of human capital at the Jordanian development banks is high.

$\mathrm{Ha}$ 2: The level of disclosure of customer (relation/ external) capital at the Jordanian development banks is high.

Ha3: The level of disclosure of structural (organizational/ internal) capital at the Jordanian development banks is high.

\section{Methodology of the study}

The descriptive analytical approach has been applied through preparing a questionnaire has been distributed over the study sample composed of the workers at the Jordanian development banks.

\section{The population and sample of the study}

The study population includes all the Jordanian developed banks. The study sample was chosen randomly; it is composed of hundred individuals working within the National Bank to Finance Small Projects.

\section{Methods of Collecting Data}

The data of this study has been collected through depending on the secondary sources of books, university transcripts, websites, and Arabic and foreign scientific journals, as well as the primary sources represented by the questionnaire being distributed over the study sample. A hundred random questionnaires were distributed to individuals working in different accounting departments at the National bank to Finance Small Projects in the different governorates of the Hashemite Kingdom of Jordan. (95) Questionnaires have been retrieved, valid for the purposes of statistical analysis with a percentage of $95 \%$ out of the total distributed questionnaires. 


\section{The used statistical methods}

The data has been analyzed using the SPSS statistical program. Cronbach's Alpha test has been used to test the internal consistency of the study tools' questions. Moreover, statistical descriptive methods have been applied, represented by percentages, repetitions, arithmetic mean, and standard deviation, as well as inferential statistics were used through using (One sample t-test) in order to test the study's hypotheses.

\section{Methods to measure the study's variables}

The study's variables have been measured through the scale of relative importance of arithmetic means. Table (1) shows this scale:

Table 1 . The scale to indicate the relative importance

\begin{tabular}{cccccc}
\hline Level & Strongly agree & Agree & Medium level & Disagree & Strongly disagree \\
\hline Scale & 5 & 4 & 3 & 2 & 1 \\
\hline
\end{tabular}

The scale of relative importance of the arithmetic mean has been determined as follows:

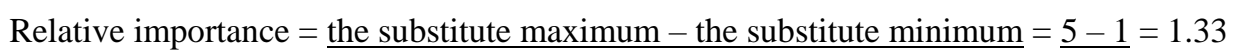

$$
\text { The number of levels }
$$

There are three levels: low, medium and high. According to this:

- Low level: when the arithmetic mean value is from1 till 2.33

- Medium level: when the arithmetic mean value is more than 2.33 till 3.66

- High level: when the arithmetic mean is more than 3.66 till 5

\section{Previous Studies}

The study of Mohammad (2015) aimed at identifying the level of disclosure of the different categories of intellectual capital in the companies' annual reports in Kurdistan for the years 20011-2014. The study sample was composed of 100 most profitable companies in different sectors in Kurdistan. This study used the Content Analysis as a framework to test the annual reports of the sample companies for the purpose of presenting an overview about the human capital reporting practices in Kurdistan. The results showed that the level of disclosure of intellectual capital in the companies' annual reports in Kurdistan was of low level.

The purpose of the study of Mansor et al. (2014) was to determine the level of disclosure of intellectual capital among the companies listed in Malesia, besides investigating the effect of intellectual capital's information over the market capital. To reach the goal of the study a sample has been chosen composed of 185 companies listed in Malesia stock market, consisting of five industries; information technology, consumer products, industrial products, trade and finance. The level of disclosure has been measured through preparing the intellectual capital disclosure indicator composed of 30 items distributed over the three dimensions of intellectual capital (human capital, structural capital and relations capital).

The results of the study showed that nearly $69 \%$ of the study sample's companies perform the disclosure of intellectual capital. The results showed as well that there is an effect for the intellectual capital information over the market capital.

The study of Córcoles (2013) identified the importance of disclosure of intellectual capital in governmental universities in Spain. To reach the study's objectives, the analytical descriptive approach has been applied through preparing a questionnaire and sending it by email to a sample made of the members of social councils in the public universities in Spain whose total number was (247) individuals.

The results of this study showed that there is a high importance for the Spanish governmental universities act of presenting information about their intellectual capital to fulfill their needs of information. The results clarified that there are lots of intellectual capital's information that shall be disclosed among which are the academic and professional qualifications of the teaching and research cadre, the scientific productivity, the educational qualifications and abilities, the efforts of innovation and development, the intellectual property and quality management.

The study of Al-Sa'idi et al. (2013) aimed at identifying the most effective dimensions of human capital over the management of organizational change. The human capital's variable was composed of the following dimensions (knowledge, capability, skills and experience). To achieve the study's objectives a questionnaire has been prepared to collect the primary data. A purposive sample has been chosen composed of (60) members of the faculties' councils in Karbala University. The answers were subject to the statistical analysis. The results showed 
that there is an effect for the human capital dimensions jointly and separately over the management of organizational change. The dimension of experience came in the first rank regarding its effect on the management process of organizational change followed by the dimension of skills then capability and finally knowledge.

The study of Mousavi et al. (2012) sought identifying the importance of disclosure of intellectual capital. To achieve the study's goal, the theoretical literature was relied on through handling the concept of disclosure of intellectual capital, its hypotheses and its relation with the market capital.

The results showed that the disclosure of intellectual capital is important and that the most important factors that determine the level of disclosure of intellectual capital are the level of transparency in the competitive markets, the organizational barriers and the auditors' conservativeness.

Dao et al. (2009) carried out a study related to the determiners of the decision of intellectual capital disclosure in the companies' annual reports in Australia. To fulfill the study goal a sample composed of (125) companies listed in the Australian stock market have been chosen. The content of these companies' reports has been studied and analyzed.

The results of the study demonstrated that the size of the company and the type of industry play an essential role as determiners of the intellectual capital disclosure. The results showed as well that there is no relation between the level of disclosure of intellectual capital and information variance.

Bhasin (2011) conducted a study that aimed at identifying the level of disclosure of intellectual capital in the companies listed in the stock market of India during the period of 2007-2009. The study depended on the Content Analysis through studying the reports of 16 companies in the sector of information technology.

The results of the study showed that there is a low level of disclosure of intellectual capital in the information technology sector in India. Moreover, they showed that the intellectual capital's components are relied on for the internal management purposes of the company without concentrating on the stakeholders from outside the company.

The study of Al-Safar (2008) aimed at identifying the effect of human capital over the banking performance in Jordan considering it as the most important component within the organization. It includes the following dimensions (the workers' knowledge, the workers' skills, the workers' experiences, the workers' spirit and the workers' ability of innovation). To achieve the goal of the study the researcher depended on personal interviews as well as he conducted a questionnaire to collect the primary data, the questionnaire was distributed over a sample of 200 workers in banks' branches in Irbid. 188 valid questionnaires have been retrieved on which the statistical analysis has been applied. The results of the study showed that there is an effect for all the human capital dimensions over the banking performance. The dimension of innovation was in the first rank regarding its effect on performance followed by knowledge, then experiences, then skills and lastly the spirit.

\section{What is distinguishes the present study about the previous studies:}

This study is distinguished among other studies by dealing with the subject of intellectual capital at the Jordanian development banks whereas through our review of previous studies we see that there are no applied studies within the development banks and that most of the studies were applied within commercial banks on the local, Arabic and foreign levels.

\section{Theoretical Framework of the Study}

The concept of intellectual capital was first handled in a practical manner in the management and accounting literature during the seventies of the last decade. It was expected that this term will become more important by the beginning of the third millennium, forming a key element in creating the organization's future wealth and its sustainability. (Al-Ali, 2003)

(Gruian, 2011) clarified that if we want to accurately identify the concept of intellectual capital, we should distinguish it from the physical capital and human capital where the physical capital is represented by the resources that appear in this organization's budget like real estate, equipment...etc. whereas the human capital is represented by the skills, creativity and accumulated experiences of the human element in the organization.

(Mention, 2012) sees the intellectual capital as the collection of available skills within the organization which are distinguished by their wide knowledge that enables the organization to become an international one through fulfilling the needs of clients, customers and external factors.

From the perspective of (Karabay, 2011) the intellectual capital is the ability to implement skills in the most critical situations. It includes the organizational knowledge and knowledge industry as well as the knowledge 
gained by training and experience, add to this the knowledge of how to run a business, avoid crisis, finding the needed information and how to obtain them.

According to (Awad \& Ghaziri, 2004), they find that the intellectual capital is composed of a group of members who use their minds more than their hands as for they have the experiences, values and knowledge as well as their ability to innovate in order to change the organization in which they work.

From the researcher's perspective, the intellectual capital of an organization is represented by an elite of workers who have a number of intellectual and organizational abilities more than others, and those abilities enable them to produce new ideas or develop old ones which enable the organization to expand its market share, maximize its strengths and position it in a way that enables the organization of seizing the appropriate opportunities. The intellectual capital is not limited to a particular administrative level and does not require the availability of an academic certificate.

\section{The Intellectual Capital Components}

Jawad (2009) explains that the intellectual capital is composed of three main components:

First: the structural (internal) capital: it includes the organization's ability to meet the market requirements and to stimulate the development of initiatives by taking into account new expectations and recognizing the new ideas, concepts and adaptive tools.

The structural capital is composed of the management processes, information systems, the organizational structure, the intellectual property and any other intangible assets owned by the organization but don't appear in its balance sheet. (Roos, 2001)

Second: the relations (external) capital: it includes all the information related to customers and their relation with the organization such as fulfilling their needs, marketing effectiveness and taking care of them. It is also composed of the basic competitive abilities, market intensity and customers' loyalty (Chen \& Lin, 2004) .

Third: the human capital: it includes knowledge, skills, qualifications and the other aspects represented by the individuals, gained throughout their lives and used in developing the organization's products. Human capital is characterized by being one of the intangible assets owned by employees like knowledge, skills, education and experience (Forbes, 2005) .

Al-Maani et al. (2011) added a fourth component for the intellectual capital which is the psychological capital represented in optimism, confidence, hope and resistance.

\section{The Importance of Disclosure of Intellectual Capital in the Financial Statements}

Accounting disclosure is an accounting principle that requires not removing or concealing any essential information that can be used in the decision making. Thus, financial statements should include explanatory reports, additional lists and accompanying statements, together with the management report and the accounting auditor's report, along with the accounting policies used, inventory details and depreciation methods (Al-Sayid, 2009) .

Disclosure is the provision of accounting information to those concerned in the form of statements and data that differ according to the desired benefit to be achieved and affected by the different parties benefiting from this information on the one hand and their different cultural level and knowledge of the reality of economic circumstances on the other hand (Al-Qadi, 2000). The principle of disclosure is linked with the emergence of joint stock companies, moreover; obligating them to publish their financial statements periodically, where the managements of these companies provide the necessary information to their investors, shareholders and lenders, represented in reports related to the results of their operations and financial position for the purpose of disclosing the essential information that occurred during the period, so the beneficiary parties have the chance to make their economic decisions based on that disclosure (Hanan, 2006).

Financial statements are considered a communication tool through which companies can show all what they have in its real value. The demonstration of intellectual capital in those statements leads to the following (Al-Sha'bani, 2011):

1- Intellectual capital forms a tool for the management efficiency on how it is using the physical resources and intangible resources in the company.

2- The disclosure of intellectual capital components in the financial statements through the following tools:

- It is a mean to enhance the relations between parties inside and outside the company as for it helps to increase the disclosure which in turns is reflected on enforcing the company's reputation. 
- It is a mean of self-development through identifying the most important flaws in the company's performance and providing the ways of training and education to resolve these flaws.

\section{The practical application of the study:}

The study tool reliability:

The reliability of the study's results has been tested through using Cronbach's Alpha test. The following table shows the results of this test for all the study's dimensions:

Table 2. Results of Cronbach's Alpha test

\begin{tabular}{lcc}
\hline \multicolumn{1}{c}{ Dimensions } & Cronbach's Alpha value (\%) \\
\hline Human capital & 80.92 \\
Customer capital & 87.62 \\
Structural capital & 75.78 \\
Intellectual capital dimensions collectively & $\mathbf{9 0 . 2 6}$ \\
\hline
\end{tabular}

Table (2) shows that the values of Cronbach's Alpha coefficient for the study's questionnaire were $80.92 \%$ for the questions related to the human capital, $87.62 \%$ for the questions related to customer capital and $75.78 \%$ for the questions related to the structural capital. Moreover, the value of the intellectual capital dimensions collectively was $90.26 \%$. This shows a strong consistency between the study questions where $(60 \%)$ is considered as the limit.

\section{Description of the personal characteristics of the study sample:}

The following table shows the personal characteristics of the study sample:

Table 3. Description of the personal characteristic of the study sample

\begin{tabular}{|c|c|c|c|c|}
\hline No. & Variable & Category & Repetition & $\begin{array}{l}\text { Percentage } \\
(\%)\end{array}$ \\
\hline \multirow{4}{*}{1} & \multirow{4}{*}{ Academic qualification } & $\begin{array}{c}\text { Community } \\
\text { college diploma }\end{array}$ & 14 & 14.7 \\
\hline & & Bachelor degree & 76 & 80.0 \\
\hline & & Master degree & 5 & 5.3 \\
\hline & & $\mathrm{PhD}$ & - & - \\
\hline \multirow[t]{3}{*}{ Total } & & & 95 & 100 \\
\hline & & General director & - & - \\
\hline & & Vice director & 4 & 4.2 \\
\hline \multirow[t]{4}{*}{2} & Position & Accountant & 8 & 8.4 \\
\hline & & Internal auditor & 6 & 6.3 \\
\hline & & Head department & 5 & 5.3 \\
\hline & & Others & 72 & 75.8 \\
\hline \multirow[t]{2}{*}{ Total } & & & 95 & 100 \\
\hline & & 5 years or less & 70 & 73.7 \\
\hline \multirow[t]{3}{*}{3} & Years of service & $6-10$ years & 23 & 24.2 \\
\hline & & $11-15$ years & 2 & 2.1 \\
\hline & & 16 years or more & - & - \\
\hline Total & & & 95 & 100 \\
\hline 4 & $\begin{array}{l}\text { Disclosure of intellectual capital is an important mean to } \\
\text { develop the banks operations and increase its competitiveness }\end{array}$ & Yes & 89 & 93.7 \\
\hline & & No & 6 & 6.3 \\
\hline Total & & & 95 & 100 \\
\hline
\end{tabular}

From table (3) we see the following:

1. Academic qualification: most of the sam ple members carry a (bachelor degree) (76) individuals with a percentage of $(80 \%)$, followed by the individuals who have (community college diploma) (14) individuals with a percentage of (14.7\%), lastly came the members who have a (master degree) (5) members with a percentage of $(5.3 \%)$.

2. Position: Most of the sample's members have (others) positions other than the ones mentioned in the questionnaire (72) members with a percentage of (75.8\%), followed by the members who work as (accountant) (8) members with a percentage of (8.4\%), followed by the members who work as (internal auditor) (6) members with a percentage of $(6.3 \%)$, then come the members who work as (head department) (5) members with a percentage of (5.3\%), finally come the members who work as (vice director) (4) members with a percentage of $(4.2 \%)$.

3. Years of service: most of the sample members have 5 or less years of service at the bank (70) members with 
a percentage of $(73.7 \%)$, followed by the members of 6-10 years of service at the bank (23) members with a percentage of $(24.2 \%)$. The members who have 11-15 years of experience were (2) members with a percentage of $(2.1 \%)$.

4. Disclosure of intellectual capital is an important mean to develop the banks operations and increase its competitiveness: most of the sample members agreed that the disclosure of intellectual capital is an important mean to develop the banks operations and increase its competitiveness. The number of members who agreed on this was (89) members with a percentage of (93.7\%) of the total sample. (6) Members of the sample didn't agree on this aspect with a percentage of $(6.3 \%)$. This shows that most of the sample members have a sufficient awareness about the importance of disclosure of intellectual capital.

\section{Discussing the Study's Dimensions}

To discuss the study's dimensions the arithmetic means of the sample's members responses have been calculated for the purpose of measuring their tendency toward the study's tool items in general. The results were as follows:

\section{The first dimension: (the disclosure of human capital):}

Table 4. The arithmetic means of the sample members' responses related to the disclosure of human capital $(\mathrm{N}=95)$

\begin{tabular}{llccc}
\hline No. & \multicolumn{1}{c}{ Item } & $\begin{array}{c}\text { Arithmetic } \\
\text { mean }\end{array}$ & $\begin{array}{c}\text { Standard } \\
\text { deviation }\end{array}$ & $\begin{array}{c}\text { Agreement } \\
\text { level }\end{array}$ \\
\hline 1 & $\begin{array}{l}\text { The bank discloses the academic qualification of its workers in its } \\
\text { financial reports. }\end{array}$ & 3.789 & 0.9988 & High \\
2 & $\begin{array}{l}\text { The bank cares about disclosing his employees' experience in its } \\
\text { financial reports. }\end{array}$ & 3.726 & 0.9044 & High \\
3 & $\begin{array}{l}\text { The bank discloses the number of its workers in its financial } \\
\text { reports. }\end{array}$ & 3.937 & 0.8850 & High \\
$\quad \begin{array}{l}\text { The bank discloses the employees' turnover in its financial } \\
\text { reports }\end{array}$ & 3.674 & 1.0152 & High \\
$\quad \begin{array}{l}\text { The bank takes into account the occupational safety and health } \\
\text { and works on incorporating its basis in its financial reports. }\end{array}$ & 4.053 & 1.0755 & High \\
Rate as a whole/ human capital & $\mathbf{3 . 8 3 6}$ & $\mathbf{0 . 9 7 5 8}$ & High \\
\hline
\end{tabular}

From table (4) we note the following:

- The answers of the sample members regarding the questions related to the disclosure of human capital headed towards agreement where the lowest value of arithmetic mean was (3.674), this shows approval in relation to question no. (4) "The bank discloses the employees' turnover in its financial reports". The highest arithmetic mean's value was (4.053) which indicate approval regarding question no. (5) "The bank takes into account the occupational safety and health and works on incorporating its basis in its financial reports".

- The rate of arithmetic means was (3.836) which demonstrate the approval regarding the disclosure of human capital. In general, the Jordanian development banks seek disclosing the items related to the human capital within their financial statements.

\section{The second dimension: (the disclosure of customer capital):}

Table 5. the arithmetic means of the sample members' answers regarding the disclosure of customer capital $(\mathrm{N}=95)$

\begin{tabular}{|c|c|c|c|c|}
\hline No. & Item & $\begin{array}{l}\text { Arithmetic } \\
\text { mean }\end{array}$ & $\begin{array}{l}\text { Standard } \\
\text { deviation }\end{array}$ & $\begin{array}{c}\text { Agreement } \\
\text { level }\end{array}$ \\
\hline 6 & $\begin{array}{l}\text { The bank discloses the academic qualification of its workers in its } \\
\text { financial reports. }\end{array}$ & 4.011 & 0.9839 & High \\
\hline 7 & The bank discloses its reputation in its financial reports & 3.947 & 0.9268 & High \\
\hline 8 & The bank discloses the employment policies in its financial reports & 3.726 & 0.9276 & High \\
\hline 9 & The bank discloses its market share in its financial reports & 3.726 & 1.0462 & High \\
\hline 10 & $\begin{array}{l}\text { The bank pays a special attention to its clients and explains its } \\
\text { policy toward them in its annual reports. }\end{array}$ & 3.884 & 0.9770 & High \\
\hline 11 & $\begin{array}{l}\text { The bank participates in the community service activities and } \\
\text { includes them in its annual reports }\end{array}$ & 4.042 & 0.9666 & High \\
\hline 12 & $\begin{array}{l}\text { The bank participates it the environmental activities and includes } \\
\text { them in its financial reports. }\end{array}$ & 3.884 & 0.9438 & High \\
\hline 13 & $\begin{array}{l}\text { The bank cares about disclosing the level of its clients' satisfaction } \\
\text { and determining the nature of the provided services in its annual } \\
\text { reports. }\end{array}$ & 3.926 & 1.0339 & High \\
\hline \multicolumn{2}{|c|}{ Rate as a whole/ human capital } & 3.893 & 0.9757 & High \\
\hline
\end{tabular}


From table (5) we note the following:

- The answers of the sample members regarding the questions related to the disclosure of customer capital headed towards agreement where the lowest value of arithmetic mean was (3.726), this shows approval in relation to questions no. (8) "The bank discloses the employment policies in its financial reports" and no. (9) "The bank discloses its market share in its financial reports". The highest arithmetic mean's value was (4.042) which indicate approval regarding question no. (11) "The bank participates in the community service activities and includes them in its annual reports".

- The rate of arithmetic means was (3.893) which demonstrate the approval regarding the disclosure of customer capital. In general, the Jordanian development banks seek disclosing the items related to the customer capital within their financial statements.

\section{The third dimension: (the disclosure of structural capital):}

Table 6. the arithmetic means of the sample members' answers regarding the disclosure of structural capital $(\mathrm{N}=95)$

\begin{tabular}{clccc}
\hline No. & \multicolumn{1}{c}{ Item } & $\begin{array}{c}\text { Arithmetic } \\
\text { mean }\end{array}$ & $\begin{array}{c}\text { Standard } \\
\text { deviation }\end{array}$ & $\begin{array}{c}\text { Agreement } \\
\text { level }\end{array}$ \\
\hline 14 & The bank cares about disclosing its patent in its financial reports. & 3.800 & 1.0169 & High \\
15 & $\begin{array}{l}\text { The bank discloses its culture in its financial reports } \\
16\end{array} \quad \begin{array}{l}\text { The bank cares about disclosing the information systems and } \\
\text { networks in its financial reports. }\end{array}$ & 3.832 & 0.9414 & High \\
$17 \quad \begin{array}{l}\text { The bank lists in its financial reports the researches and } \\
\text { developments that have been applied and planned for. }\end{array}$ & 3.905 & 1.0322 & High \\
$18 \quad \begin{array}{l}\text { The bank shows in its financial reports the management } \\
\text { operations that take place within the bank. }\end{array}$ & 3.790 & 0.8503 & High \\
Rate as a whole/ structural capital & $\mathbf{3 . 8 2 9}$ & $\mathbf{0 . 9 5 2 4}$ & High \\
\hline
\end{tabular}

From table (6) we note the following:

- The answers of the sample members regarding the questions related to the disclosure of structural capital headed towards agreement where the lowest value of arithmetic mean was (3.790), this shows approval in relation to questions no. (18) "The bank shows in its financial reports the management operations that take place within the bank". The highest arithmetic mean's value was (3.905) which indicate approval regarding question no. (16) "The bank cares about disclosing the information systems and networks in its financial reports".

- The rate of arithmetic means was (3.829) which demonstrate the approval regarding the disclosure of structural capital. In general, the Jordanian development banks seek disclosing the items related to the structural capital within their financial statements.

\section{Testing the study hypotheses:}

To test the statistical acceptance of the hypothesis, (One Sample T-Test) has been applied. The hypothetical mean value (3) was considered as the hypothesis acceptance criterion at $(\alpha=0.05)$. The results were as follows:

\section{The results of testing the first hypothesis:}

Ha1: the level of disclosure of human capital at the Jordanian development banks is of high level.

Table 7. The results of applying (One Sample T-Test) over the dimension of human capital

\begin{tabular}{|c|c|c|c|c|c|}
\hline ion & etic & d & tion & $\mathbf{T}$ & el \\
\hline $\begin{array}{l}\text { disclosure of human } \\
\text { tal }\end{array}$ & 36 & 9 & High & 11.055 & \\
\hline \multicolumn{6}{|c|}{$\begin{array}{l}\text { From the previous table we see that the }(\mathrm{T}) \text { value regarding the questions related to the level of disclosure } \\
\text { human capital was }(11.055) \text { with a statistical significance of }(0.000) \text { which is a positive statistically significa } \\
\text { value at }(\alpha \leq 0.05) \text {. Moreover, the value of the arithmetic mean was (3.836) with a high level of approval. Base } \\
\text { on this, the null hypothesis is rejected and its alternative is accepted: "the level of disclosure of human capital } \\
\text { the Jordanian development banks is of high level". }\end{array}$} \\
\hline
\end{tabular}

\section{The results of testing the second hypothesis:}

$\mathrm{Ha} 2$ : the level of disclosure of customer (relations/ external) capital at the Jordanian development banks is of high level. 
Table 8. The results of applying (One Sample T-Test) over the dimension of customer capital

\begin{tabular}{lccccc}
\hline Dimension & $\begin{array}{c}\text { Arithmetic } \\
\text { mean }\end{array}$ & $\begin{array}{c}\text { Standard } \\
\text { deviation }\end{array}$ & $\begin{array}{c}\text { Evaluation } \\
\text { level }\end{array}$ & T & $\begin{array}{c}\text { The statistical } \\
\text { significance }\end{array}$ \\
\hline $\begin{array}{l}\text { The disclosure of customer } \\
\text { capital }\end{array}$ & $3 . .893$ & 0.7148 & High & 12.182 & 0.000 \\
\hline
\end{tabular}

From the previous table we see that the (T) value regarding the questions related to the level of disclosure of customer capital was (12.182) with a statistical significance of $(0.000)$ which is a positive statistically significant value at $(\alpha \leq 0.05)$. Moreover, the value of the arithmetic mean was (3.893) with a high level of approval. Based on this, the null hypothesis is rejected and its alternative is accepted: "the level of disclosure of customer capital at the Jordanian development banks is of high level".

\section{The results of testing the third hypothesis:}

Ha3: the level of disclosure of structural (organizational/ internal) capital at the Jordanian development banks is of high level.

Table 9. The results of applying (One Sample T-Test) over the dimension of structural capital

\begin{tabular}{lccccc}
\hline Dimension & $\begin{array}{c}\text { Arithmetic } \\
\text { mean }\end{array}$ & $\begin{array}{c}\text { Standard } \\
\text { deviation }\end{array}$ & $\begin{array}{c}\text { Evaluation } \\
\text { level }\end{array}$ & T & $\begin{array}{c}\text { The statistical } \\
\text { significance }\end{array}$ \\
\hline $\begin{array}{l}\text { The disclosure of structural } \\
\text { capital }\end{array}$ & $3 . .830$ & 0.6804 & High & 11.882 & 0.000
\end{tabular}

capital

From the previous table we see that the (T) value regarding the questions related to the level of disclosure of structural capital was (11.882) with a statistical significance of (0.000) which is a positive statistically significant value at $(\alpha \leq 0.05)$. Moreover, the value of the arithmetic mean was (3.830) with a high level of approval. Based on this, the null hypothesis is rejected and its alternative is accepted: "the level of disclosure of structural (organizational /internal) capital at the Jordanian development banks is of high level".

The conclusion of these results shows that the results of the current study are different from the results of the study of Mohammad (2015) which clarified that the level of disclosure of human capital in the companies' annual reports in Kurdistan is of low level. Moreover, the results of this study also differ from the study of Bhasin (2011) which clarified the existence of a low level of disclosure of the intellectual capital in the information technology sector in India. Whereas the results of the current study comply with the study of Mansor (2014) which reviled a percentage of $69 \%$ of the intellectual capital disclosure within the companies in Malesia, as well as the study of Córcoles (2013) which showed the existence of a high importance for the Spanish governmental universities to provide information about their intellectual capital for the sake of fulfilling their needs of information, in addition; the results of the current study complies with the results of the study of Mousavi et al (2012) which emphasized the importance of disclosure of intellectual capital through following the theories of intellectual capital.

\section{Results}

This study aimed at identifying the level of disclosure of intellectual capital at the Jordanian development banks. The following results were concluded:

1- The level of disclosure of human capital at the Jordanian development banks is of high level.

2- The level of disclosure of customer (relations/ external) capital at the Jordanian development banks is of high level.

3- The level of disclosure of structural (organizational/ internal) capital at the Jordanian development banks is of high level.

4- Most of the members working at the Jordanian development banks have a high level of awareness toward the importance and necessity of disclosure of the intellectual capital's items from the perspective that it forms the basis of conducting the banking operations.

\section{Recommendations}

1- The necessity of Jordanian development banks to increase the awareness of their employees concerning the importance of disclosing the intellectual capital in their financial statements through holding the necessary training courses.

2- The need to pay attention to the human capital in the Jordanian development banks by identifying their needs and accept all the ways that contribute to their development and increase their job growth.

3- The need to work on consolidating the relationships with customers continuously through knowing their 
desires and the use of different assessment methods that express their views towards the staff of the bank and the provided banking services.

4- The need to pay attention to the organizational structure of the bank through the modernization of the information network of the bank and working on the development of its objectives and vision according to the needs of sophisticated dealers.

5- Applying this study over commercial banks and Islamic banks for the purpose of conducting a comparison between them and the development banks.

\section{References}

First: Arabic references

Al-Hafiz, M. H. (2012). The Individual Human Intellectual Capital as a Share in the Partrenships' Capital. Mansour Journal, 17, 239-259.

Al-Maani, A., Ariqat, A., Al-Saleh, A., \& Jardat, N. (2011), Modern Management Issues, Dar Wael for Publishing, Amman, Jordan.

Al-Qadi, H. (2000), International Accounting, first issue, Dar Al Thaqafa, Amman, Jordan.

Al-Sa'idi, M. G., HUsein, H., \& Wadi, A. G. (2013). The Effect of Human Capital in the Management of Organizational Change: an Analytical Study for the Views of the Faculty Councils Members of Karbala University. AL-Qadisiyah Journal for Administrative and Economic sciences, 15(2), 31-57.

Al-Safar, A. A. I. (2008). The Impact of Human Capital on the Banking Performance: an Analytical Study of the Views of Workers at the Jordanian Commercial Banks. Journal of Management and Economy, 70, 84-108.

Al-Sayid, S. A. A. (2009). The Modern Accounting Concepts, Dar Al-Raya for publishing, Amman, Jordan.

Hanan, R. H. (2006). Modern Accounting Model, second edition, Dar Wael for publishing, Amman, Jordan.

Jawad, N. (2009). Analyzing the Intellectual Capital as a Strategic Tool. Al Ghiri. Journal of Economic and Administrative Sciences, 5(14), 129-150.

Qabajah, A. A. A. (2008). "The Effect of Institutional Governance on the Financial Performance of Companies Listed in Palestine Stock Market", PhD thesis, Amman Arab University, Amman, Jordan.

Saleh, I. Y., \& Al-Sha'bani. (2011). "The Effect of Intellectual Capital on the Technological Proficiency and its Impact on Cost Reduction by Applying This on the National Company of Home Furniture Industries in Ninawa". Al-Anbar University Journal of Economic and Administration Sciences, 4(7).

Second: English references

Abdifatah, H., \& Nazli, G. (2013).A Longitudinal examination of Intellectual Capital Disclosures and Corporate Governance Attributes in Malaysia. Asian Review of Accounting, 21 (1), 27-52. https://doi.org/10.1108/13217341311316931

Al- Ali, N. (2003). Comprehensive Intellectual Capital Management: Step by Step, John Wily \& Sons, Inc, Hoboken, New Jersey, U.S.A.

Awad, E., \& Ghaziri, H. (2004). Knowledge management, Person Education International, Prentice - Hall N.Y.

Bhasin, M. (2011). Disclosure of Intellectual Capital in Annual Reports: An Empirical Study of the Indian IT Corporations. Modern Economy, 2, 455-467. https://doi.org/10.4236/me.2011.24051

Chen, H., \& Lin, K. (2004). The Role of Human Capital Cost in Accounting. Journal of Intellectual Capital, 5(3), 6-30.

Córcoles, Y. (2013). Importance of intellectual capital disclosure in Spanish universities, Intangible Capital, 9(3), 931-944.

Dao, M., Vergauwen, P., \& Brüggen, A. (2009). Determinants of intellectual capital disclosure: evidence from Australia, Management Decision, Emerald Group Publishing Limited, 47(2), 233-245.

Forbes, P. (2005). Managerial Determinants of Decision Speedin New Ventures. Strategic Management Journal, 26(4), 355-365. https://doi.org/10.1002/smj.451

Gruian, C. (2011). The Influence of Intellectual Capital on Romanian Companies' Financial Performance. Annales Universities Apulensis Series Economics, 13(2).

Hui, T. (2007). Disclosure standards and market efficiency: Evidence from analysts' forecasts. Journal of 
International Economics, 72(1), 222-241. https://doi.org/10.1016/j.jinteco.2006.11.004

Karabay, M. (2011), Assessing the Measurement of Intangible Assets in Telecommunication Sector: Evidence from Turkey, International Journal of Business and Management Studies, 3(1), 239- 252.

Mansor, M., Mustafa, N., \& Taliyang, S. (2014). Intellectual Capital Disclosure and Market Capitalization. International Journal of Business and Social Science, 5(10), 96-102.

Mention, A. (2012). Intellectual Capital, Innovation and Performance: A Systematic Review of the Literature. Business and Economic Research, 2(1), 1-37. https://doi.org/10.5296/ber.v2i1.1937

Mohammad, A. (2015). Human Capital Disclosures: Evidence from Kurdistan. European Journal of Accounting Auditing and Finance Research, 3(3), 21-31.

Mousavi, Z., Mazraeh, S., \& Neysi, S. (2012). The Importance of Intellectual Capital Disclosure. International Journal of Business and Social Science, 3(15), 307-310.

Roos, G., Bainbridge, A., \& Jacobsen, K. (2001). Intellectual Capital Analysis as a Strategic Tool. Strategy and Leadership, 29(4), 21-26. https://doi.org/10.1108/10878570110400116

\section{Copyrights}

Copyright for this article is retained by the author(s), with first publication rights granted to the journal.

This is an open-access article distributed under the terms and conditions of the Creative Commons Attribution license (http://creativecommons.org/licenses/by/4.0/). 